
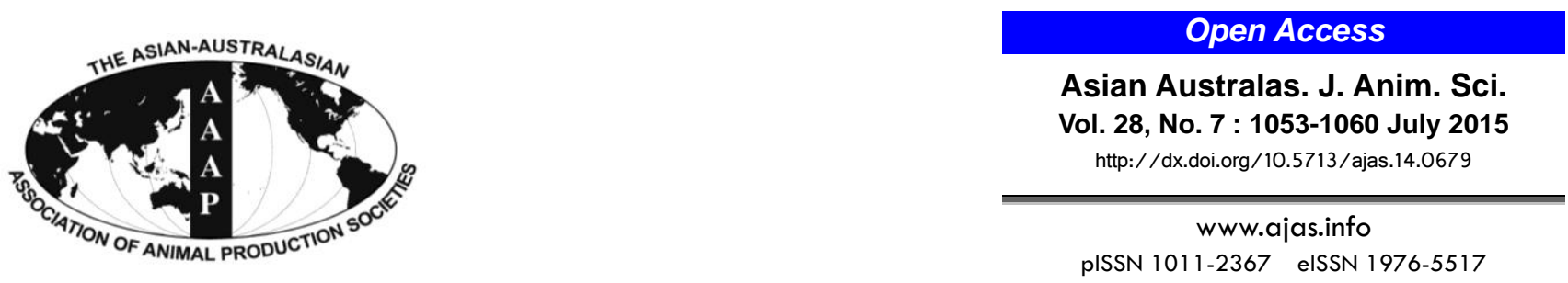

\title{
Struvite Crystallization of Anaerobic Digestive Fluid of Swine Manure Containing Highly Concentrated Nitrogen
}

\author{
Eun Young Lee*, Min Hwan Oh, Seung-Hak Yang ${ }^{1}$, and Tae Han Yoon ${ }^{2}$ \\ Department of Environmental Engineering, The University of Suwon, Suwon 445-743, Korea
}

\begin{abstract}
In this study, the optimal operation factors for struvite crystallization for removing and recovering nitrogen and phosphorus from anaerobic digestive fluid of swine manure containing highly concentrated nitrogen was determined. Every experiment for the struvite crystallization reaction was conducted by placing $1,000 \mathrm{~mL}$ of digestion fluid in a 2,000 mL Erlenmeyer flask at various temperatures, $\mathrm{pH}$, and mixing speed. Except for special circumstances, the digestion fluid was centrifuged (10,000 rpm, $10 \mathrm{~min})$ and then the supernatant was used for the experiment at room temperature and $100 \mathrm{rpm}$. The optimal mole ratio of $\mathrm{PO}_{4}{ }^{3-}: \mathrm{Mg}^{2+}$ was $1: 1.5$, and the $\mathrm{pH}$ effect ranging from 9 to 11 was similar, when mixed for 1 hour. Under this condition, the removal efficiency of $\mathrm{NH}_{4}{ }^{+}-\mathrm{N}$ and $\mathrm{PO}_{4}{ }^{3-}-\mathrm{P}$ was $40 \%$ and $88.6 \%$, respectively. X-shaped crystal was observed by light and scanning electron microscopy. In addition, struvite crystal structure was confirmed through X-ray diffraction analysis. (Key Words: Struvite, Anaerobic Digestive Fluid, Swine Manure)
\end{abstract}

\section{INTRODUCTION}

Large-scale livestock breeding has become a serious social problem with respect to the storage and treatment of livestock manure. The waste generated in the process of handling livestock manure contains a large amount of nitrogen and phosphorus, which are the main agents causing eutrophication. If the waste is discharged or an excessive amount is used as a fertilizer on soil without proper treatment, environmental problems can occur. Solid and liquid composting are widely used as resource recovery methods for the disposal of domestic livestock manure, and biological treatment is predominantly used for the purification of urine and wastewater. However, because the soil is not sufficiently secured for distributing fertilizers, it is desirable to produce safe and high quality fertilizers by

\footnotetext{
* Corresponding Author: Eun Young Lee. Tel: +82-31-220-2614, Fax: +82-31-221-9357, E-mail: ley@ suwon.ac.kr

${ }^{1}$ Animal Environment Division, National Institute of animal Science, RDA, Suwon 441-706, Korea.

${ }^{2}$ Dodram Environment Research Center Co. Ltd, Icheon 467-842, Korea.

Submitted Sept. 2, 2014; Revised Oct. 19, 2014; Accepted Oct. 25, 2014
}

decomposing the manure and storing or transporting it for future use. Treatment costs of livestock manure with water contents above $97 \%$ are high because it is necessary to mix a large amount of sawdust or husk. Moreover, this manure is highly likely to become sawdust compost, in which the content of the fertilizer active ingredient is low. In addition, during the manufacturing of liquid fertilizer, highly concentrated ammonium is present, and therefore, the fertilizer is strongly aerated to remove the bad odor. Accordingly, most of the ingredients undergo nitrification to produce the content of the fertilizer active ingredient low. Further, it is difficult to handle and transport the fertilizer because it is liquid. The fertilization period is fixed according to the state of the domestic farming industry, and thus, it is difficult to spray fertilizers in autumn and winter. Thus, tremendous amounts of liquid fertilizer are stored. Although there is a necessity for the recovery of livestock resources, civil complaints have been filed due to the odor emanating from the treatment process; the product is also a low quality fertilizer, with low added value, and thus becomes a nuisance.

Unless the quality of life is improved and meat consumption is reduced, domestic livestock farming will

Copyright (c 2015 by Asian-Australasian Journal of Animal Sciences This is an open-access article distributed under the terms of the Creative Commons Attribution Non-Commercial License (http://creativecommons.org/licenses/by-nc/3.0/) which permits unrestricted non-commercial use, distribution, and reproduction in any medium, provided the original work is properly cited. 
continue to increase. Recovering the energy in manure is a good method of disposing the constantly increasing livestock manure more effectively. Currently, the method mostly used for this is the production of biogas through anaerobic digestion. However, this method creates problems related to disposing the solid and anaerobic digestion wastewater that remains after energy recovery.

Anaerobic digestion fluid contains more highly concentrated nitrogen and phosphorus than ordinary livestock wastewater, and thus, it is very difficult to meet the reinforced water quality standard for anaerobic digestion fluid. Anaerobic digestion liquid can cause bad odor and contains high-molecular substances that have chromaticity. Thus, if this liquid flows into a river or lake without treatment, the increase in chromaticity could cause a decrease in the transillumination of the aquatic ecosystem, which could lead to secondary problems including degradation of the self-purification capacity of the ecosystem and the reproduction of pathogenic bacteria. Due to such problems, most treatment facilities face difficulties in disposing of highly concentrated nitrogen and phosphorus in anaerobic digestion liquid. If the organic fertilizer ingredients, which are largely contained in the livestock wastewater or anaerobic digestion fluid, are powdered or solidified, they can be conveniently transported to other regions. It would also be possible to use them all-year round like chemical fertilizers and this would reduce the amount sprayed on farmlands; thus, it is thought that there would be an effect of reducing the number of workers. Further, when the fertilizer used in the farmland is in the form of urea, only $40 \%$ of $\mathrm{N}$ is used as fertilizer by plants and the rest is swept away in various forms (Liang et al., 2007); a large amount (26.5\% to 29.4\%) is also discharged as greenhouse gases such as $\mathrm{N}_{2} \mathrm{O}$. Since the heat absorption rate of $\mathrm{N}_{2} \mathrm{O}$ is higher than that of $\mathrm{CO}_{2}, \mathrm{~N}_{2} \mathrm{O}$ contributes to global warming by more than about 300 times that of $\mathrm{CO}_{2}$ (Hallett, 2002). When struvite is used as a fertilizer, the plant absorbs all the $\mathrm{N}$ due to struvite's slow releasing characteristics (Lee et al., 2009) and this can also minimize $\mathrm{N}_{2} \mathrm{O}$ emissions (Chu et al., 2007).

In the Netherlands, in order to recover and recycle phosphorus from livestock manure, manure is completely incinerated and the ashes are recycled (Willem et al., 2001). Ren et al. (2014), Enhanced adsorption of phosphate by loading Nanosized Ferric Oxyhydroxide on anion resin. Currently in South Korea, the source materials needed in the phosphorus-related industry are imported from other countries. The exhaustion of phosphorus is a global concern, and, therefore, securing sources for replacing phosphorus is an urgent problem (Moriyama et al., 2001; Frank and Mark, 2009). As a practical measure to this problem, struvite crystallization, which is a chemicophysical treatment method, is mainly being studied, and the phosphorus generated and recovered through such processes is available as high-priced fertilizer in some countries including Japan (Moriyama et al., 2001; Ueno and Fujii, 2001).

Struvite, generally called guanite or magnesium ammonium phosphate (MAP), is combined with a $\mathrm{NH}_{4}{ }^{+}: \mathrm{Mg}^{2+}: \mathrm{PO}_{4}^{-}$mole ratio of $1: 1: 1$. Struvite crystallization has advantages in that it can process highly concentrated nitrogen and phosphorus at the same time, the detention period is short, there is no need for another facility, and the site area can be reduced (Jo et al., 2003; Kim et al., 2006; Weon et al., 2009). In particular, the wastewater generated after the thermophilic digestion contains highly concentrated phosphorus and thus can reduce the injection volume of outer phosphorus $\left(\mathrm{PO}_{4}{ }^{3-}\right)$ that is required in the crystallization. The subjects of struvite studies until now have included livestock wastewater, sewage water, and anaerobic digestion fluid. The concentration of early total chemical oxygen demand (TCOD) values and $\mathrm{NH}_{4}{ }^{+}-\mathrm{N}$ of the studied wastewater was about $2,700 \mathrm{mg} / \mathrm{L}$ and 1,700 to $2,000 \mathrm{mg} / \mathrm{L}$ on average. However, the treatment of TCOD and $\mathrm{NH}_{4}{ }^{+}-\mathrm{N}$ in anaerobic digestive fluid of swine wastewater containing highly concentrated nitrogen is a significant problem with respect to factors such as recovery rate.

Thus, in this study, struvite crystallization was conducted using thermophilic aerobic digestion sludge fluid of swine manure containing $17,125 \mathrm{mg} / \mathrm{L}$ of TCOD, 3,534 $\mathrm{mg} / \mathrm{L}$ of total Kjeldahl nitrogen. During the crystallization reaction, the influence of factors affecting the treatment of highly concentrated ammonia nitrogen and phosphorus such as $\mathrm{pH}$, mixing time (td) and mixing intensity $(\mathrm{G})$, injection volume of magnesium and phosphorus, and temperature were analyzed.

\section{MATERIALS AND METHODS}

\section{Wastewater characteristics}

The wastewater used in this study comprised the supernatant of anaerobic digestive fluid of swine manure containing highly concentrated nitrogen and phosphorus. The characteristics of the wastewater are shown in Table 1;

Table 1. Characteristics of the thermophilic anaerobic digestion fluid

\begin{tabular}{lcc}
\hline Parameter & Concentration range & Average \\
\hline TCOD $(\mathrm{mg} / \mathrm{L})$ & 15,900 to 18,600 & 17,125 \\
TKN $(\mathrm{mg} / \mathrm{L})$ & 3,100 to 4,046 & 3,534 \\
TSS $(\%)$ & 3.08 to 3.26 & 3.15 \\
VSS $(\%)$ & 56.15 to 62.18 & 59.08 \\
$\mathrm{NH}_{4}{ }^{+}-\mathrm{N}(\mathrm{mg} / \mathrm{L})$ & 2,974 to 3,907 & 3,400 \\
$\mathrm{PO}_{4}{ }^{3-}-\mathrm{P}(\mathrm{mg} / \mathrm{L})$ & 1,120 to 1,468 & 1,342 \\
$\mathrm{pH}$ & 8.10 to 8.26 & 8.15 \\
\hline
\end{tabular}

TCOD, total chemical oxygen demand; TKN, total Kjeldahl nitrogen; TSS, total suspended solid; VSS, volatile suspended solid. 
the average concentration of ammonia nitrogen and phosphate phosphorus was $3,400 \mathrm{mg} / \mathrm{L}$ and $1,342 \mathrm{mg} / \mathrm{L}$, respectively. The ratio of the ammonia nitrogen to the total nitrogen of the subject wastewater was over $96 \%$, and the ratio of the phosphate phosphorus to the total phosphate was over $77 \%$, confirming that the wastewater was appropriate for struvite crystallization. T-COD of this anaerobic digestive fluid was $17,125 \mathrm{mg} / \mathrm{L}$, which was very highly concentrated nitrogen containing wastewater.

\section{Experimental materials}

A 1,000 mL beaker was used in the experiment and the amount of wastewater was set to $900 \mathrm{~mL}$. The reagent used in the struvite crystallization was $\mathrm{MgCl}_{2} \cdot 6 \mathrm{H}_{2} \mathrm{O}$. Every experiment for the struvite crystallization reaction of anaerobic digestive fluid of swine manure was conducted by placing $1,000 \mathrm{~mL}$ of digestion fluid in a $2,000 \mathrm{~mL}$ Erlenmeyer flask at various temperatures, $\mathrm{pH}$, and mixing speed. Except for special circumstances, the digestion fluid was centrifuged $(10,000 \mathrm{rpm}, 10 \mathrm{~min})$ and then the supernatant was used for the experiment at room temperature and $100 \mathrm{rpm}$. The $\mathrm{pH}$ of the digestion fluid was controlled by adding $5 \mathrm{~N} \mathrm{NaOH}$ before the addition of $\mathrm{MgCl}_{2} \cdot 6 \mathrm{H}_{2} \mathrm{O}$, and by mixing the fluid through the impeller. Experimental conditions were shown in Table 2.

\section{The influence of initial pH during struvite crystallization}

To observe the influence of $\mathrm{pH}$ during the struvite crystallization reaction, $1,000 \mathrm{~mL}$ of anaerobic digestion supernatant was placed in the prepared beaker and evenly mixed at $100 \mathrm{rpm}$. After measuring the initial $\mathrm{pH}$ and temperature, magnesium and phosphate phosphorus were injected to obtain a $\mathrm{Mg}^{2+}: \mathrm{PO}_{4}{ }^{3-}$ mole ratio of $1: 1$. The initial $\mathrm{pH}$ of the wastewater was 8.3 , and thus the $\mathrm{pH}$ was set to 9, $10,11,12$, and 13 by adding $5 \mathrm{~N} \mathrm{NaOH}$ after injecting magnesium. After the struvite crystallization reaction, the volume of the precipitates was measured 10 minutes after precipitation to check the treatment efficiency of ammonia nitrogen and phosphorus after the crystallization. Then, the obtained supernatant was filtered with $0.45 \mu \mathrm{m}$ syringe filters.

\section{Influence of mixing time and intensity during struvite crystallization}

During the struvite crystallization reaction, the mixing time was set to 10 minutes, 60 minutes, and 24 hours, and the intensity was variously set to $100 \mathrm{rpm}$ and $200 \mathrm{rpm}$. Here, the reaction $\mathrm{pH}$ was not adjusted, as the phosphate removal efficiency in a previous experimental result was similar in the range from 9 to 13 . After the struvite crystallization reaction, the volume of the precipitates was measured after 10 minutes, 1 hour, and 24 hours of precipitation to check the treatment efficiency of ammonia nitrogen and phosphorus after the crystallization. After that, the mixing intensity increased to $200 \mathrm{rpm}$ for 24 hour reaction. In this reaction, magnesium and phosphate phosphorus mole ratio $\left(\mathrm{Mg}^{2+}: \mathrm{PO}_{4}{ }^{3-}\right)$ was $1: 1.5$, which has been determined to be the optimal mole condition as it resulted in the maximum phosphate removal efficiency in a previous experimental result. Then, the obtained supernatant was filtered and analyzed with $0.45 \mu \mathrm{m}$ syringe filters.

\section{Optimal mole ratio of $\mathrm{Mg}^{2+}$ and $\mathrm{PO}_{4}{ }^{3}-\mathrm{P}$}

In this study, a large amount of $\mathrm{NH}_{4}{ }^{+}-\mathrm{N}$ was present in the wastewater making it impossible to obtain the ratio of $1: 1: 1$ that is generally used in the process of crystallizing struvite. Thus, with a focus on the recovery of phosphorus, the optimal injection amount of $\mathrm{Mg}^{2+}$ and $\mathrm{PO}_{4}{ }^{3}-\mathrm{P}$ was determined. After preparing $1,000 \mathrm{~mL}$ of the subject wastewater, the injected mole ratio was altered by setting 1 as the reference point in order to derive the optimal injection amount. Here, the $\mathrm{pH}$ not adjusted before injecting $\mathrm{Mg}$ and the reaction was conducted at room temperature at $100 \mathrm{rpm}$ for 1 hour.

\section{Analysis method}

Analysis of every sample used in this study was conducted after filtering the samples with $0.45 \mu \mathrm{m}$ syringe filters in order to remove the floating materials in the samples. The ammonia nitrogen was measured using a HACH DR-5000 and analyzed using the Salicylate method in the HACH DR-4000 manual (DR5000, HACH Inc., Loveland, CO, USA). Phosphorus was analyzed by using the Molybdovanadate method.

Table 2. Experimental conditions of struvite crystallization

\begin{tabular}{|c|c|c|c|}
\hline \multirow{2}{*}{ Parameters } & \multicolumn{3}{|c|}{ Conditions } \\
\hline & Test 1 & Test 2 & Test 3 \\
\hline 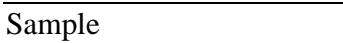 & \multicolumn{3}{|c|}{ Anaerobic digestion supernatant of swine manure, $1 \mathrm{~L}$} \\
\hline $\mathrm{pH}$ & $\mathrm{pH} 9,10,11,12,13$ & $\mathrm{pH} 8.8$ & $\mathrm{pH} 8.8$ \\
\hline Molar ratio of $\mathrm{PO}_{4}{ }^{3-}: \mathrm{Mg}^{2+}$ & $1: 1$ & 1.5 & $\begin{array}{c}1: 1,1,1,1,2, \\
1,3,1,4,1: 1.5\end{array}$ \\
\hline Agitating velocity, temp. & 100 rpm, Room temp. & $100 \mathrm{rpm}, 200 \mathrm{rpm}$, Room temp. & 100, Room temp. \\
\hline Reaction time & $1 \mathrm{~h}$ & $10 \mathrm{~min}, 1 \mathrm{~h}, 24 \mathrm{~h}$ & $1 \mathrm{~h}$ \\
\hline
\end{tabular}


The $\mathrm{pH}$ meter (Orionstar, ThermoScientific, Walthem, MA, USA) was calibrated after each experiment. After struvite crystallization, the precipitates were dried at room temperature, and the type and shape of the crystals were identified through X-ray diffraction (XRD) analysis (using the X-ray diffractometer of Advance D8, Bruker Co., Billerica, MA, USA) and standard error of the mean (scanning electron microscopy) measurements (using JSM5600, JEOL Co., Tokyo, Japan).

\section{RESULTS AND DISCUSSION}

\section{Influence of early $\mathrm{pH}$ on struvite crystallization}

Factors such as the concentration of $\mathrm{Mg}^{2+}$, ratio of $\mathrm{Mg}^{2+}$, $\mathrm{NH}_{4}^{+}$, and $\mathrm{PO}_{4}{ }^{3-}, \mathrm{pH}$, temperature, aeration rate, and presence of $\mathrm{Ca}^{2+}$ significantly affect struvite crystallization (Yetilmezsoy and Zengin, 2009). In particular, $\mathrm{pH}$ is extremely important. Generally, the solubility of struvite increases according to increases in $\mathrm{pH}$, and thus it is desirable to induce crystallization by maintaining a high $\mathrm{pH}$ in order to remove nitrogen and phosphorus. The influence of $\mathrm{pH}$ change in the struvite crystallization reaction of anaerobic digestion fluid with an average concentration of ammonia nitrogen is shown in Figure 1. As shown in the figure, the removal efficiency of ammonia nitrogen has a wide range, from $\mathrm{pH} 9$ to $\mathrm{pH} 13$. However, ammonia nitrogen was more effectively removed in an environment with $\mathrm{pH}$ over 12 . The removal efficiency was $33.1 \%, 52.6 \%$, and $54.9 \%$ at $\mathrm{pH} 11,12$, and 13 , respectively. Previous studies have reported that the most appropriate $\mathrm{pH}$ for struvite crystallization of swine manure and sewage water is alkaline condition such as 8 to 12 (Lee et al., 2010; Rahman et al., 2011; Ye et al., 2011; Hutnik et al., 2013).

A removal of phosphorus was observed in wide range of

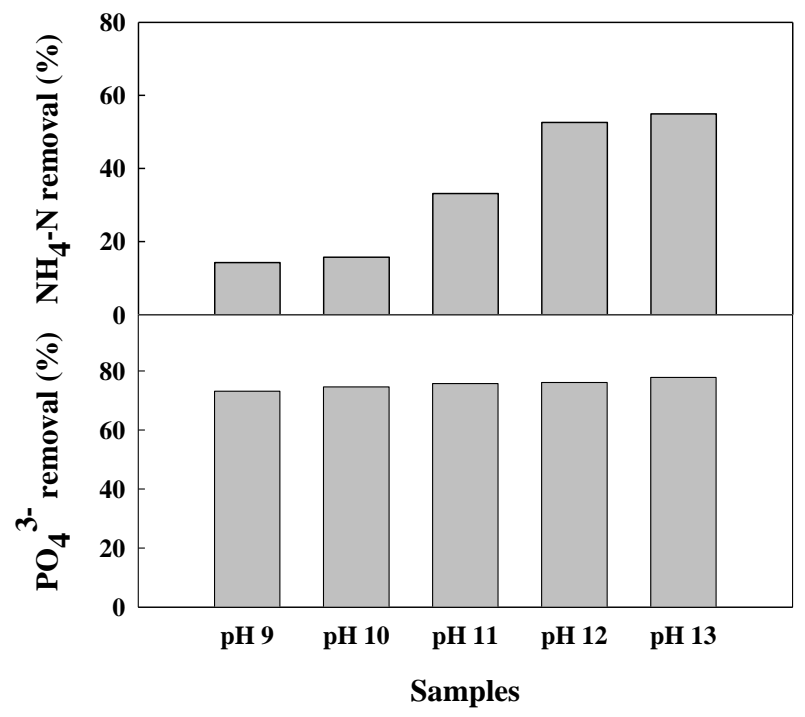

Figure 1. Effect of the initial $\mathrm{pH}$ on the struvite crystallization of anaerobic digestive fluid of swine manure.
$\mathrm{pH}$ from 9 to 13 (Figure 1) in this research. The removal efficiency was $73.0 \%$, and $77.8 \%$ at $\mathrm{pH} 9$, and 13 , respectively. With the increase in $\mathrm{pH}$, the solubility of struvite decreased, but it has been reported that the added $\mathrm{Mg}^{2+}$ forms coagulations such as $\mathrm{Mg}(\mathrm{OH})_{2}$, which cause relatively low $\mathrm{NH}_{4}{ }^{+}-\mathrm{N}$ removal efficiency (Choo et al., 2011). The $\mathrm{pH}$ is an extremely significant factor in struvite crystallization, and in consideration of the ratio of the chemicals, it would be most effective to remove phosphorus and nitrogen through only a simple mixing under weak alkaline conditions.

\section{Influence of mixing time and intensity during struvite crystallization}

During struvite crystallization, aeration rate plays an important role in removing ammonia. Air flow volatilizes and removes dissolved ammonia through mixing in the wastewater. Moreover, air flow becomes the driving force, which dilutes the concentration of gas-phase $\mathrm{NH}_{4}{ }^{+} \mathrm{N}$ and separates the dissolved $\mathrm{NH}_{4}{ }^{+}-\mathrm{N}$ from the gas-phase. It has been reported that sufficient aeration time can enable the effective removal of ammonia (Yetilmezsoy and Zengin, 2009). Yetilmezsoy and Zengin (2009) reported that $\mathrm{NH}_{4}{ }^{+}$$\mathrm{N}$ in the reactor could be removed by up to $95.3 \%$ by mixing at a speed of $0.6 \mathrm{~L} \cdot \mathrm{m}^{-1}$ for 24 hours (Yetilmezsoy and Zengin, 2009). Liu et al. (2011b, c) stated that the formation of struvite in the reactor is proportional to the aeration rate, and that it reaches a plateau at a speed of 0.73 $\mathrm{L} \cdot \mathrm{m}^{-1}$. According to Suzuki et al. (2007) and Battistoni et al. (1997), the $\mathrm{pH}$ of wastewater increased with the aeration because of $\mathrm{CO}_{2}$ stripping (Suzuki et al., 2007). They also stated that at an aeration rate of $12 \mathrm{~m}^{3} \cdot \mathrm{h}^{-1}$, the $\mathrm{pH}$ was within 7.5 and 8 , and that at an aeration rate of $16 \mathrm{~m}^{3} \cdot \mathrm{h}^{-1}$, the $\mathrm{pH}$ increased from 8.0 to 8.5. According to Choo et al. (2011), struvite crystallization is not largely affected when the mixing time is set between $1 \mathrm{~min}$ and $30 \mathrm{~min}$ and when the mixing intensity is set to over $85 \mathrm{~s}^{-1}$. Kim et al. (2006) stated that the $\mathrm{NH}_{4}{ }^{+}-\mathrm{N}$ and $\mathrm{PO}_{4}{ }^{3}-\mathrm{P}$ removal efficiency was $75 \%$ and $89 \%$ within 5 minutes, and $82.1 \%$ and $96.8 \%$ at 10 minutes, respectively, and that the efficiency did not increase after 10 minutes (Kim et al., 2006). Although there was slight difference in the time of arriving at the maximum efficiency, they inferred that the maximum efficiency was arrived at within a short time span of between 0 min and 30 $\min$.

In this study, $\mathrm{NH}_{4}{ }^{+}-\mathrm{N}$ showed $37 \%$ removal under the condition of $1 \mathrm{~h}$, and then, it increased to $80 \%$ for $24 \mathrm{~h}$ reaction (Figure 2). It was considered because of the nitrogen $\left(\mathrm{CO}_{2}\right)$ stripping effect. In the case of $\mathrm{PO}_{4}{ }^{3}-\mathrm{P}$, the increasing reaction time from $10 \mathrm{~min}$ to $24 \mathrm{~h}$ did not have a large influence on the crystallization (about $88 \%$ removal) and changing the mixing speed between $100 \mathrm{rpm}$ and 200 rpm had the same result. 


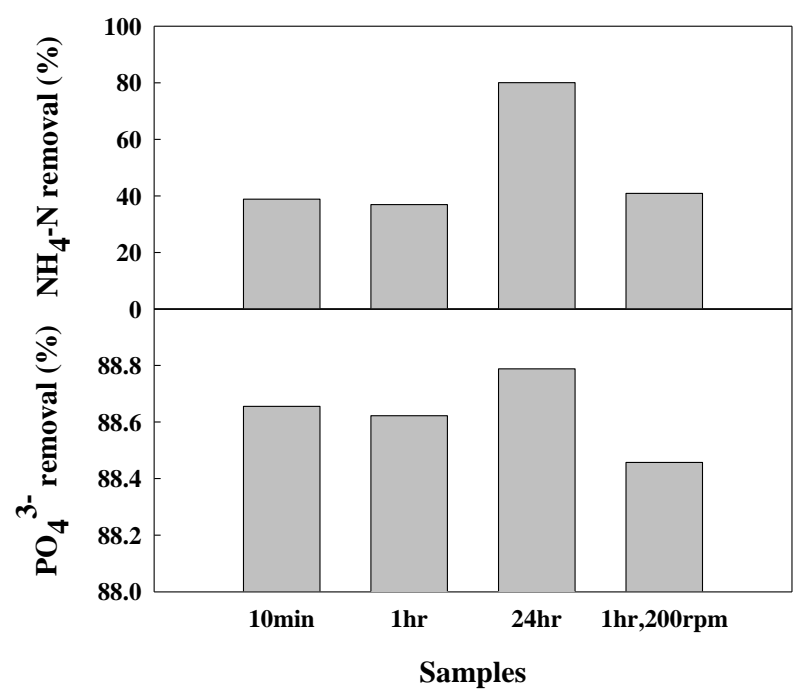

Figure 2. Effect of mixing time on the struvite crystallization of anaerobic digestive fluid of swine manure. ${ }^{*}$ This experiment was done at $200 \mathrm{rpm}$ for $1 \mathrm{~h}$; others (without asterisk) were done at $100 \mathrm{rpm}$ for $10 \mathrm{~min}, 1 \mathrm{~h}$, and $24 \mathrm{~h}$.

\section{Optimal injection amount of $\mathbf{M g}^{2+}$}

It has been reported that, in general, for $\mathrm{NH}_{4}-\mathrm{N}, \mathrm{COD}$, and chromaticity removal, there is no major difference when using $\mathrm{MgSO}_{4} \cdot 6 \mathrm{H}_{2} \mathrm{O}$ or $\mathrm{MgCl}_{2} \cdot 6 \mathrm{H}_{2} \mathrm{O}$ as the samples for struvite crystallization (Yetilmezsoy and Zengin, 2009). However, it has been reported that when $\mathrm{MgO}$ is used, $\mathrm{Mg}(\mathrm{OH})_{2}$ raises the total suspended solid and, thus, reduces the $\mathrm{NH}_{4}-\mathrm{N}$ removal efficiency. However, the $\mathrm{Ca}^{2+}$ in the wastewater reacts with $\mathrm{PO}_{4}$ generating substances such as hydroxyapatite, dicalcium phosphate, and octacalium phosphate. Thus, it has been reported that the generation of calcium phosphate inhibits struvite crystallization (Doyle and Parsons, 2002).

The ratio of $\mathrm{PO}_{4}{ }^{3} \mathrm{P}: \mathrm{Mg}^{2+}$ that is known to be appropriate for struvite crystallization is either $1: 1$ or $1: 1.2$ (Rahman et al., 2011). According to Yetilmezsoy and Zengin (Yetilmezsoy and Zengin, 2009), the $\mathrm{N}$ and COD removal rate is lower when the ratio of $\mathrm{Mg}^{2+}: \mathrm{NH}_{4}{ }^{+}: \mathrm{PO}_{4}{ }^{2-}$ is lower $(0.5: 1: 1,0.8: 1: 1,1: 1: 0.5,1: 1: 0.8)$ than the high mole ratio $(1.2: 1: 1,1.5: 1: 1,1: 1: 1.2,1: 1: 1.5)$.

The concentration ratio of $\mathrm{NH}_{4}{ }^{+}-\mathrm{N}$ and $\mathrm{PO}_{4}{ }^{3}-\mathrm{P}$ was approximately $30: 1$ in the livestock wastewater, and therefore, the phosphorus removal efficiency was high while the ammonia removal efficiency was low. In consideration of such characteristics of anaerobic digestive fluid of swine manure, the $\mathrm{PO}_{4}{ }^{3}-\mathrm{P}$ dissolved in the wastewater was taken as the reference point in this study in order to determine the addition ratio. Accordingly, $\mathrm{PO}_{4}{ }^{3}-\mathrm{P}$ : $\mathrm{Mg}_{2}{ }^{+}$was altered to be $1: 1,1: 1.1,1: 1.2,1: 1.3,1: 1.4$, and $1: 1.5$, and then the removal efficiency of $\mathrm{NH}_{4}{ }^{+}-\mathrm{N}$ and $\mathrm{PO}_{4}{ }^{3}-\mathrm{P}$ was measured (Figure 3). As a result, the $\mathrm{NH}_{4}{ }^{+}-\mathrm{N}$ removal efficiency $(40 \%)$ was highest when $1.2 \mathrm{M}^{\circ} \mathrm{Mg}^{2+}$

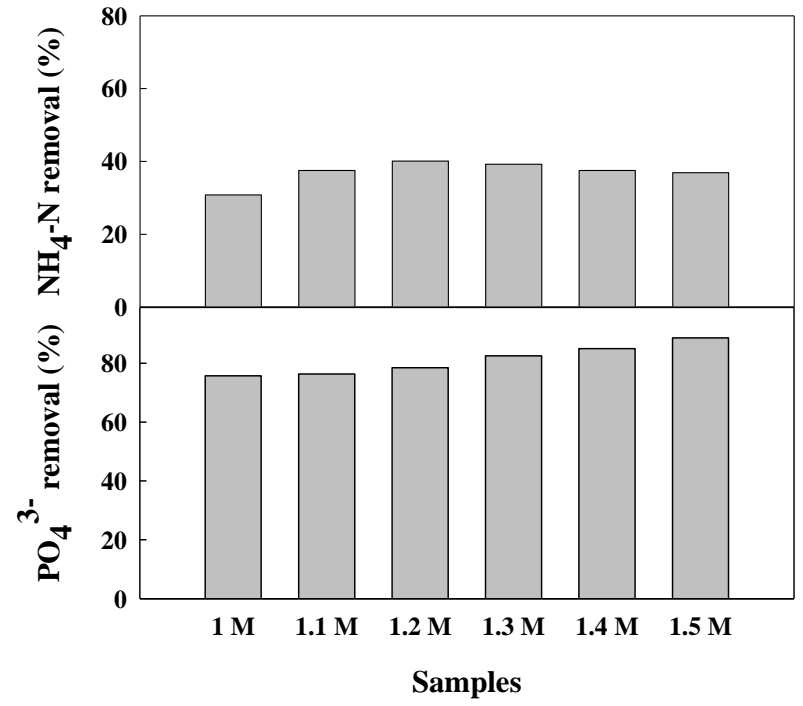

Figure 3. Effect of $\mathrm{PO}_{4}{ }^{2-}-\mathrm{P}$ to $\mathrm{Mg}^{2+}$ mole ratio on the struvite crystallization of anaerobic digestive fluid of swine manure.

was added. In the subsequent concentration, the removal efficiency showed a tendency to decrease. The $\mathrm{PO}_{4}{ }^{3}-\mathrm{P}$ removal efficiency increased from $75 \%$ to $88 \%$ as the amount of added $\mathrm{Mg}^{2+}$ increased from $1.0 \mathrm{M}$ to $1.5 \mathrm{M}$, respectively.

It has been reported that although all the $\mathrm{PO}_{4}{ }^{3}-\mathrm{P}$ participates in the crystallization of struvite at the optimal injection amount, above that level it forms substances such as hydroxyapatite by reacting with other spilt or dissolved ions (Dorozhkin, 2010; Capdevielle et al., 2013). There are several studies reporting that, generally, in the crystallization of struvite, an injection mole ratio of $\mathrm{NH}_{4}{ }^{+}: \mathrm{Mg}^{2+}: \mathrm{PO}_{4}{ }^{3-}$ higher than $1: 1: 1$, which is the theoretical mole ratio, is necessary. This appears to result from the consumption of injected $\mathrm{Mg}$ due to the crystallization of substances such as calcium dissolved in the wastewater through reaction with substances such as $\mathrm{PO}_{4}{ }^{3-}-\mathrm{P}$, or the formation of amorphous precipitate or complex compounds such as $\mathrm{Mg}(\mathrm{OH})_{2}$ and $\mathrm{MgHPO}_{4} \cdot 3 \mathrm{H}_{2} \mathrm{O}$ (Schulze-Rettmer, 1991).

The optimal mole ratio can differ according to the type and characteristics of the wastewater used in the struvite crystallization because of the variation of the dissolved $\mathrm{NH}^{4+}-\mathrm{N}$ and $\mathrm{PO}_{4}{ }^{3}-\mathrm{P}$ concentrations. The theoretical optimal value of $1: 1: 1$ cannot be achieved because the $\mathrm{NH}_{4}{ }^{+}: \mathrm{PO}_{4}{ }^{3-}$ ratio of wastewater cannot be $1: 1$, and, thus, when the $\mathrm{PO}_{4}{ }^{3}-\mathrm{P}$ concentration is lower, the values of the variables in the reaction can vary. Generally, the ammonia removal rate is within $20 \%$ to $40 \%$ (Cho et al., 2009; Ye et al., 2011), and the phosphorus removal rate is relatively high, ranging from $67 \%$ to a maximum of $99 \%$ (Kim et al., 2004; Liu et al., 2011a). 

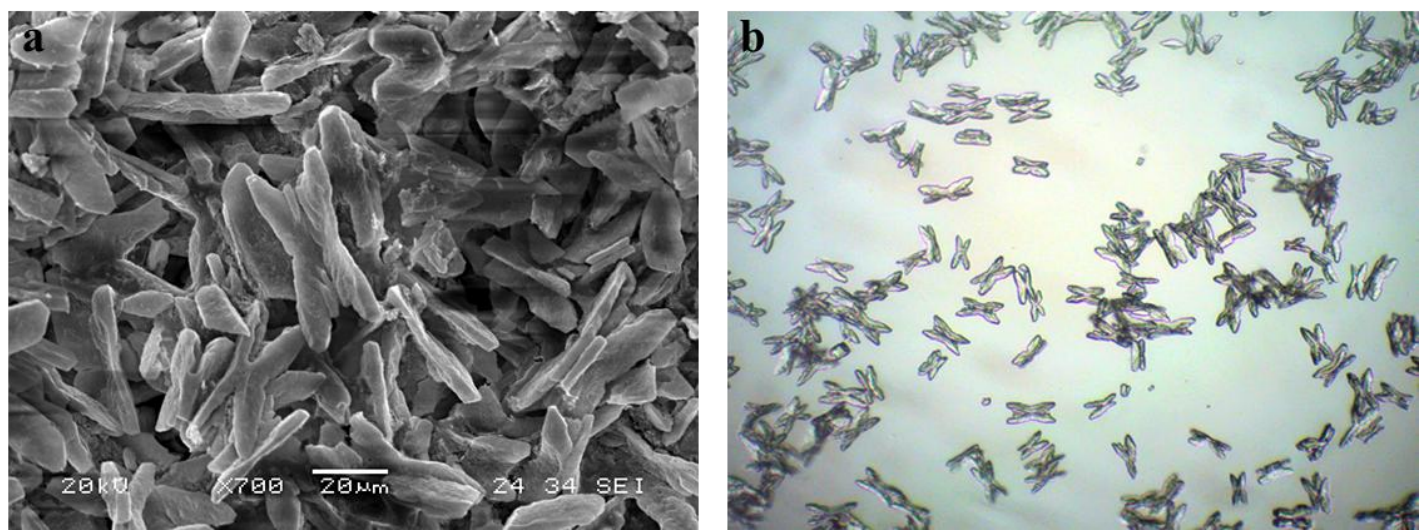

Figure 4. Microscopic pictures of struvite crystal morphology: scanning electron microscopy at $\mathrm{pH} 8.8$ with magnification of $\times 700$ (a), light microscopy at $\mathrm{pH} 8.8$ with magnification of $\times 100(\mathrm{~b})$; The measure bars on (a) indicate $20 \mu \mathrm{m}$.

\section{Observation of struvite crystallization}

Figure 4 shows the microscopic picture of the struvite crystal generated by adding the $\mathrm{MgCl}_{2} \cdot 6 \mathrm{H}_{2} \mathrm{O}$. Figure $4 \mathrm{a}$ was the scanning electron microscope image of the MAP (magnesium ammonium phosphate) crystal generated by mixing the $\mathrm{MgCl}_{2} \cdot 6 \mathrm{H}_{2} \mathrm{O}$ for 5 days at $100 \mathrm{rpm}$ and $\mathrm{pH} 8.8$. The morphology was $\mathrm{X}$-shaped branch crystal and the size was about 45 to $55 \mu \mathrm{m}$. Figure $4 \mathrm{~b}$ was the light microscope image with a magnification of 100 times.

It has been reported that the MAP crystal generated in livestock wastewater tends to be treated repetitively and increases in size as time passes. Ueno and Fujii (2001) reported that the size of a struvite crystal grows by 0.5 to 1 $\mathrm{mm}$ during a 10 day-long reaction, and Schulze-Rettmer et al. (2001) reported that a crystal with a size of $1 \mathrm{~cm}$ was found in their manure storage tank. Published morphology types range from coffin-like (Wierzbicki et al., 1997) and needle-like (Abbona and Boistelle, 1985) to trapezoidal (Munch and Barr, 2001). All of these forms are described as 'typical for struvite'. In our experiment, X-shaped branched crystals were observed. This shape was reported by Mariska et al. (2010).

The solids obtained in the experiments were subjected to XRD analysis. The powdered XRD pattern of synthetic and struvite pellets matched very well with that of the published pattern for struvite (Figure 5). The slight

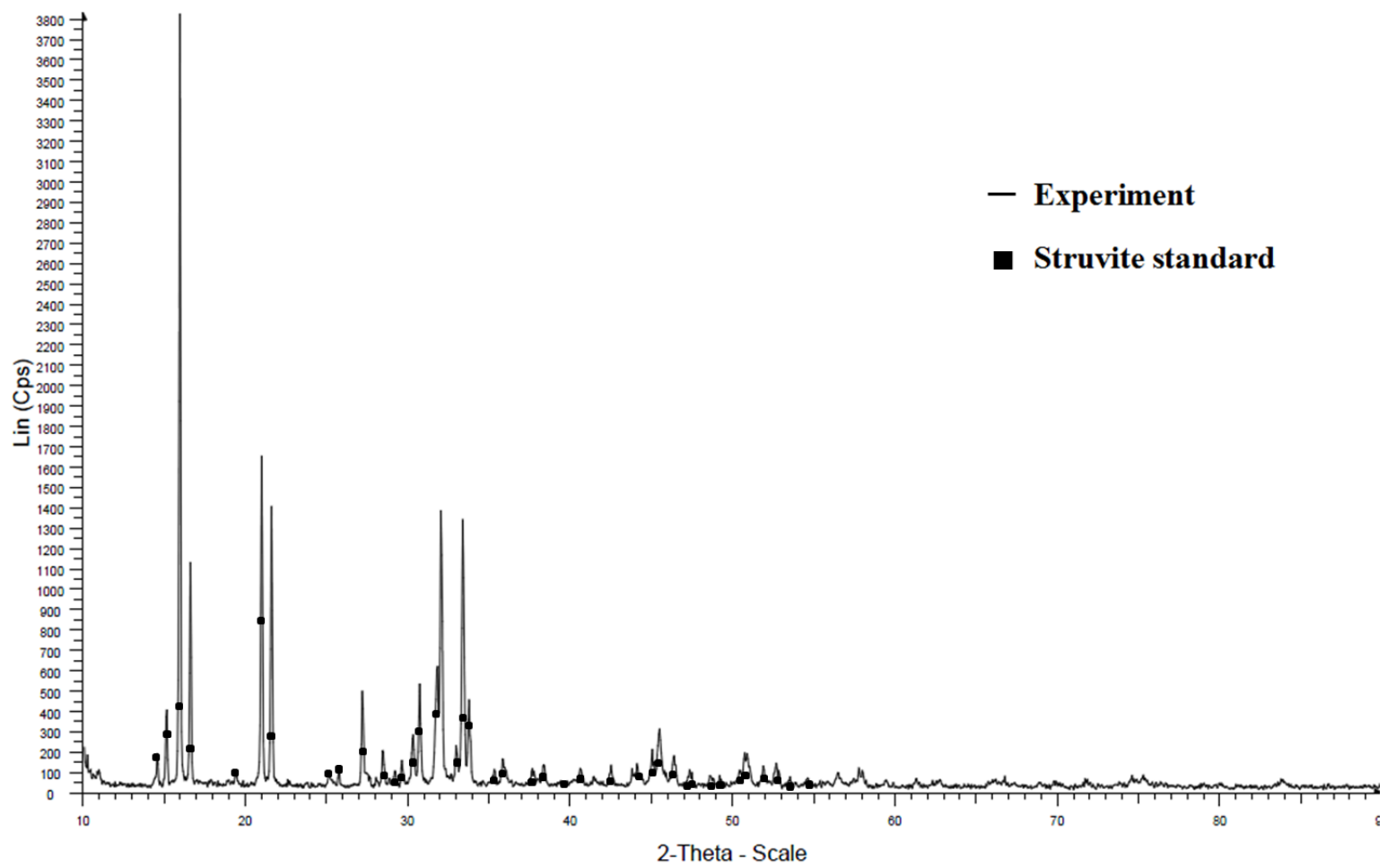

Figure 5. X-ray diffraction patterns of struvite crystal. 
difference between the XRD patterns of the two kinds of struvite may be due to the amount of impurity present in the struvite pellets. Infrared (IR) spectra for both synthetic struvite and struvite pellets were also consistent with the published IR spectrum of struvite in the wave number range of 400 to $4,000 \mathrm{~cm}^{-1}$ with $100 \%$ recovery of spectra according to the standards. As such, the struvite samples were considered to be a single-phase material.

\section{CONCLUSION}

Struvite crystallization using the anaerobic digestive fluid of swine manure containing highly concentrated nitrogen is a highly effective and eco-friendly process that can collect or remove phosphorus and nitrogen. If the potential hazardous substances in wastewater are not removed before being placed in an ecosystem, it can result in eutrophication. However, if they are collected, they can be precious resources. The effect of $\mathrm{pH}$, temperature, reaction mixing speed, and the $\mathrm{Mg}^{2+}: \mathrm{PO}_{4}{ }^{3-}$ ratios, which are important factors that affect the struvite crystallization reaction, was determined. In this study, approximately $88 \%$ of $\mathrm{P}$ and $40 \%$ of $\mathrm{N}$ were removed and collected from the existing livestock wastewater through struvite crystallization. However, even if the $\mathrm{N}$ removal efficiency is low, a tremendous amount of nitrogen in the wastewater can be removed through ammonia stripping. Struvite is an important material that can become a major source of slowrelease fertilizers using phosphorus even after the phosphorus in the phosphorus mines is completely exhausted.

\section{ACKNOWLEDGMENTS}

This study was supported by the Korea Environmental Industry \& Technology Institute of the Ministry of Environment as a Next-generation Eco-innovation Research Project (Project No. 413-112-010).

\section{REFERENCES}

Abbona, F. and R. Boistelle. 1985. Nucleation of struvite: single crystals and agglomerates. Cryst. Res. Technol. 20:133-140.

Battistoni, P., G. Fava, P. Pava, A. Musacco, and F. Cecchi. 1997. Phosphate removal in anaerobic liquors by struvite crystallization without addition of chemicals: Preliminary results. Water Res. 31:2925-2929.

Capdevielle, A., E. Sykorova, B. Biscans, F. Beline, and ML. Daumer. 2013. Optimization of struvite precipitarion in synthetic biologically treated swine wastewaterDetermination of the optimal process parameters. J. Hazard. Mater. 244-245:357-369.

Cho, J. H., J. E. Lee, and C. S. Ra. 2009. Microwave irradiation as a way to reutilize the recovered struvite slurry and to enhance system performance. J. Anim. Sci. Technol. (Korea) 51:337342.

Choo, Y. D., K. Y. Kim, H. D. Ryu, and S. I. Lee. 2011. Treatment of N, P of auto-thermal thermophillic aerobic digestion fluid with struvite crystallization. J. Kor. Soc. Environ. Engineers. 33:783-789.

Chu, H., Y. Hosen and K. Yagi. 2007. NO, $\mathrm{N}_{2} \mathrm{O}, \mathrm{CH}_{4}$, and $\mathrm{CO}_{2}$ fluxes in winter barley field of Japanese Andisol as affected by $\mathrm{N}$ fertilizer management. Soil Biol. Biochem. 39:330-339.

Dorozhkin, S. V. 2010. Amorphous calcium (ortho)phosphates. Acta Biomater. 6:4457-4475.

Doyle, J. D. and S. A. Parsons. 2002. Struvite formation, control and recovery. Water Res. 36:3925-3940.

Frank, B. and L. Mark. 2009. Sewage treatment and methods for phosphate recovery in BCFS process. Second International Conference on the Recovery of Phosphorus from Sewage and Animal Wastes. March 12-13, 2009; Noordwikerhout, The Netherlands.

Hallett, J. 2002. Intergovernmental Panel on Climate Change (IPCC). Climate change 2001: the scientific basis. Contribution of Working Group I to the Third Assessment Report of the Intergovernmental Panel on Climate Change. Cambridge University Press, Cambridge, UK.

Hutnik, N., B. Wierzbowska, K. Piotrowski, and A. Matynia. 2013. Continuous reaction crystallization of struvite from solution containing phosphate(V) and nitrate(V) ions. Online J. Sci. Technol. 3:58-66.

Jo, W. S., S. J. Yoon, and C. S. Ra. 2003. Recovery of N and P resources from animal wastewater by struvite crystallization. J. Anim. Sci. Technol. 45:857-884.

Kim, B. U., W. H. Lee, H. J. Lee, and J. M. Rim. 2004. Ammonium nitrogen removal from slurry-type swine wastewater by pretreatment using struvite crystallization for nitrogen control of anaerobic digestion. Water Sci. Technol. 49:215-222.

Kim, J. O., J. T. Jung, and H. K. Kim. 2006. Removal of nitrogen and phosphorus in anaerobic fermentation supernatant by struvite crystallization. J. Korea. Geo. Environ. Soc. 7:5-12.

Lee, J. E., M. M. Rahman, and C. S. Ra. 2009. Does effects of Mg and $\mathrm{PO}_{4}$ sources on the composting of swine manure. J. Hazard. Mater. 169:801-809.

Lee, J. E., J. H. Kwag, and C. S. Ra. 2010. Influence of compost recycling and magnesium supplement on physical and chemical traits of animal manure compost. J. Anim. Sci. Technol. (Korea) 52:513-519.

Liang, X. Q., Y. X. Chen, H. Li, G. M. Tian, W. Z. Ni, M. M. He, and Z. J. Zhang. 2007. Modeling transport and fate of nitrogen from urea applied to a near-trench paddy field. Environ. Pollut. 150:313-320.

Liu, Y. H., J. H. Kwag, J. H. Kim, and C. S. Ra. 2011a. Recovery of nitrogen and phosphorus by struvite crystallization from swine wastewater. Desalination 277:364-369.

Liu, Y. H., M. M. Rahman, J. H. Kwag, J. H. Kim, and C. S. Ra. 2011b. Eco-friendly production of maize using struvite recovered from swine wastewater as a sustainable fertilizer source. Asian Australas. J. Anim. Sci. 24:1699-1705.

Liu, Y. H., S. Kumar, J. H. Kwag, J. H. Kim, and C. S. Ra. 2011c. Recycle of electrolytically dissolved struvite as an alternative 
to enhance phosphate and nitrogen recovery from swine wastewater. J. Hazard. Mater. 195:175-181.

Mariska, R., M. Max, H. Rainer, and G. Willi. 2010. Struvite precipitation from urine - Influencing factors on particle size. Water Res. 44:2038-2046.

Munch, E. and K. Barr. 2001. Controlled struvite crystallization for removing phosphorus from anaerobic digester sidestreams. Water Res. 35:151-159.

Moriyama, K., T. Kojima, Y. Minawa, S. Matsumoto, and K. Nakamachi. 2001. Development of antificial seed crystal for crystallization of calcium phosphate. Second International Conference on the Recovery of Phosphorus from Sewage and Animal Wastes. March 12-13, 2001; Noordwikerhout, The Netherlands.

Rahman, M. M., Y. H. Liu, J. H. Kwag, and C. S. Ra. 2011. Recovery of struvite from animal wastewater and its nutrient leaching loss in soil. J. Hazard. Mater. 186:2026-2030.

Ren, J., N. Li, L. Zhao, and N. Ren. 2014. Enhanced adsorption of phosphate by loading nanosized ferric oxyhydroxide on anion resin. Front. Environ. Sci. Eng. 84:531-538.

Schulze-Rettmer, R. 1991. The simultaneous chemical precipitation of ammonium and phosphate in the form of magnesium-ammonium-phosphate. Water Sci. Technol. 23:659-667.

Schulze-Rettmer, R., P. Metzen, A. Alfter, and B. Simbach. 2001. MAP precipitation for recovering nutrients from manure. Second International Conference on the Recovery of Phosphorus from Sewage and Animal Wastes. March 12-13, 2001; Noordwikerhout, The Netherlands.
Suzuki, K., Y. Tanaka, K. Kuroda, D. Hanajima, Y. Fukumoto, T. Yasuda, and M. Waki. 2007. Removal and recovery of phosphorous from swine wastewater by demonstration crystallization reactor and struvite accumulation device. Bioresour. Technol. 98:1573-1578.

Ueno, Y. and M. Fujii. 2001. 3 year operating selling recovered struvite from full-scale plant. Second International Conference on the Recovery of Phosphorus from Sewage and Animal Wastes. March 12-13, 2001; Noordwikerhout, The Netherlands.

Weon, S. Y., S. K. Park, and S. I. Lee. 2009. Removal of nitrogen and phosphorus using struvite crystallization. Environ. Eng. Res. 22:599-607.

Wierzbicki, A., J. D. Sallis, E. D. Stevens, M. Smith, and C. S. Sikes. 1997. Crystal growth and molecular modeling studies of inhibition of struvite by phosphocitrate. Calcif. Tissue Int. 61:216-222.

Willem, S., K. Bram, P. Berend, R. Wim, T. Hardy, K. Ferdinand, and L. Lijimbach. 2001. Phosphate recycling in the phosphorus industry. Second International Conference on the Phosphorus from Sewage and Animal Wastes. March 12-13, 2001; Noordwikerhout, The Netherlands.

Ye, Z. L., S. H. Chen, M. Lu, J. W. Shi, L. F. Lin, and S. M. Wang. 2011. Recovering phosphorus as struvite from the digested swine manure with bittern as a magnesium source. Water Sci. Technol. 64:334-340.

Yetilmezsoy, K. and Z. S. Zengin. 2009. Recovery of ammonium nitrogen from the effluent of UASB treating poultry manure wastewater by MAP precipitation as a slow release fertilizer. J. Hazard. Mater. 166:260-269. 